Contribution to The Knowledge of Carabodid Oribatid Mites (Acari, Oribatida, Carabodidae) of Turkey, With Ecological And Zoogeographical Remarks

\author{
Ayşe TOLUK ${ }^{1}$, Nusret AYYILDIZ ${ }^{2}$ \\ 1,2Department of Biology, Faculty of Science, Erciyes University, 38039 Kayseri, Turkey \\ ${ }^{1}$ https://orcid.org/0000-0003-1787-505X, ${ }^{2}$ https://orcid.org/0000-0002-5602-1033 \\ $\triangle$ : nayildiz@erciyes.edu.tr
}

\section{Research Article}

$\begin{array}{ll}\text { Article History } & \\ \text { Received } & : 04.05 .2020 \\ \text { Accepted } & : 02.10 .2020\end{array}$

Keywords

Carabodid mites

Ecology

Distribution

Taxonomy

Turkey

\title{
Türkiye'nin Carabodid Oribatid Akarları (Acari, Oribatida, Carabodidae) Bilgisine Ekolojik ve
} Zoocoğrafik Açıklamalar İle Katkı

\begin{abstract}
ÖZET
Carabodidae Koch, 1837 familyasından yedi oribatid akar, isim olarak, Austrocarabodes (s.str.) ensifer (Sellnick, 1931), A. (s.str.) foliaceisetus foliaceisetus Krivolutsky, 1971, Carabodes (s.str.) labyrinthicus (Michael, 1879), C. (s.str.) pirinensis Kunts, 1961, C. (s.str.) rugosior Berlese, 1916, C. (Flexa) djaparidzae Murvanidze ve Weigmann, 2007 ve C. (Flexa) dubius Kulijev, 1968 Türkiye'den tarama elektron mikroskobu görüntüleri ile birlikte verilir. A. (s.str.) ensifer (Sellnick, 1931) dışındaki diğer altı tür Türkiye oribatid faunası için yeni kayıttır. Taksonlar aynı zamanda ekolojik ve zoocoğrafi bakımından da değerlendirilir. Ayrıca Türkiye carabodid cins ve türleri için de bir teşhis anahtarı verilir.
\end{abstract}

\section{Araștırma Makalesi}

$\begin{array}{ll}\text { Makale Tarihçesi } \\ \text { Geliş Tarihi } & : 04.05 .2020 \\ \text { Kabul Tarihi } & : 02.10 .2020\end{array}$

Anahtar Kelimeler

Carabodid akarlar

Ekoloji

Dağılım

Taksonomi

Türkiye

To Cite : Toluk A, Ayyıldız N 2021. Contribution to The Knowledge of Carabodid Oribatid Mites (Acari, Oribatida, Carabodidae) of Turkey, With Ecological And Zoogeographical Remarks. KSU J. Agric Nat 24 (3): 650-662. https://doi.org/ 10.18016/ksutarimdoga.vi.731745.

\section{INTRODUCTION}

Oribatid mites constitute one of the most important groups of organisms in taxonomic, ecological and zoogeographical aspects due to their presence in almost all kinds of habitats and biogeographic regions, high adaptability, slow movement, strong interaction with microenvironments and their roles in soil structure and decomposition process (Gergócs and Hufnagel 2009, Schuppenhauer et al. 2019). Since the 1980's, Ayyıldız and his collaborators have made a significant contributions to the knowledge of the oribatid mite fauna of Turkey (Ayyıldız 1989, Ayyıldız and Luxton 1989a, 1989b, 1990, Baran and Ayyldez 2008, Toluk et al. 2008, Toluk and Ayyıldız 2009a, 2009b, 2011; Baran et al. 2009, 2012, Ayylldiz et al. 2016, Toluk 2016, Susyal et al. 2018, Ay and Ayylldı 2019a, 2019b). So far, the number of known species and subspecies of oribatid mites in Turkey is 245 (Baran et al. 2018). The family Carabodidae which is the subject of the present study, is one of the largest families in the oribatid mites with 33 genera after the families Oppiidae (132 genera) and Microzetidae (45 genera) (Subías 2004). A limited number of studies are available on this group and so far, only three taxa (viz. Austrocarabodes (A.) ensifer (Sellnick, 1931), Carabodes (Flexa) intermedius Willmann, 1951 and Carabodes (Klapperiches) pulcher pulcher (Bernini, 1976) belonging to the genera Austrocarabodes and Carabodes have been known from Turkey (Ayyldız 1988, Per and Ayyıldız 2005, Yalçın et al. 2013).

The present study on carabodid mites constitute a new addition to the taxonomic, ecological and zoogeographical investigations on oribatid mites in Turkey. 


\section{MATERIALS and METHODS}

The material used in this study was obtained from samples previously collected by the authors and kept in the collection, in the context of the determination of Turkish oribatid mite fauna. More detailed information was given in the material examined of each taxon in Results section. They were extracted using a Berlese funnel apparatus, and preserved in $70 \%$ ethanol. The specimens were sorted from the samples under a stereomicroscope and mounted on slides in modified Hoyer's medium. Body length was measured in lateral view, from the tip of the rostrum to the posterior edge of the ventral plate. Notogastral width refers to the maximum width in dorsal aspect. Photographs were taken by the Scanning Electron Microscope (SEM). The terminology used in this paper follows Norton and Behan-Pelletier (2009). We prepared the species distribution map by using Website (http://encarta.softwaresea.com/Windowssoftware-download/encarta-maps). The specimens examined were deposited in the Acarological Collection of the Zoological Museum of Erciyes University, Kayseri, Turkey.

\section{RESULTS}

\section{Family Carabodidae Koch, 1843}

Key to the known genera and subgenera of the family Carabodidae from Turkey

1. Ten pairs of notogastral setae

Carabodes Koch, 1835..... 2

Fourteen pairs of notogastral setae

Austrocarabodes Hammer, 1966

2. Epimeral setal formula: 1-1-3-3, Interlamellar setae originating in interlamellar region C. (Klapperiches) Mahunka, 1979

Epimeral setal formula: 3-1-3-3 or 2-1-3-3. Interlamellar setae originating on the surface of lamellae .............................................. 3

3. Setae $c_{2}$ long, directed forwards, all other notogastral setae short, phylliform. Lyrifissure iad situated in adanal position

C. (Flexa) Kulijev, 1977

Setae $c_{2}$ directed outwards or backwards, never forwards. Lyrifissure iad absent or originating far from anal aperture . (Carabodes) C. L. Koch, 1835

Key to the known species and subspecies of the family Carabodidae from Turkey

1- Fourteen pairs of notogastral setae .....................2

-Ten pairs of notogastral setae ..............................

2 - Sensillus fusiform, notogaster surface covered with a reticulated pattern formed by a varying number of rounds, small tubercles Austrocarabodes (Austrocarabodes) ensifer

- Sensillus setiform, notogastral surface covered by well-developed round tubercles

\section{$A$. (A.) foliaceisetus foliaceisetus}

3- Setae $c_{2}$ normal 4
- Setae $c_{2}$ very long, directed forward ....................7 4- Setae in originating in interlamellar region ...C. (Klapperiches) pulcher pulcher

-Setae in on the surface of lamellae .......................5

5- Interlamellar region with two protuberances C. (Carabodes) rugosior

- Interlamellar region with ridges .......................6 6

6- Setae in long; notogastral surface with areolae and pustules C. (C.) pirinensis

- Setae in short; notogastral sculpture with joint tubercles C. (C.) labyrinthicus

7- Notogastral setae phylliform ........................ 8 Notogastral setae lanceolate ....................................... C. (Flexa) intermedius

8- Interlamellar region covered by irregular ridges C. (F.) djaparidzae

-Interlamellar region with several short longitudinal grooves in two rows.. C. (F.) dubius

\section{Genus Austrocarabodes Hammer, 1966}

Austrocarabodes (Austrocarabodes) ensifer (Sellnick, 1931)

Measurements: Body length: 464-520, body width: 240 $-288 \mu \mathrm{m}(\mathrm{n}=10)$.

Diagnosis (Figure 1): Lamellae without cuspis. All dorsal setae phylliform. Lamellar setae inserted on distal lateral surface of lamellae; interlamellar setae originating close to inner margin of lamellae. Prodorsum with irregular polygonous areas. Sensillus head gradually thickened and rounded distally. Dorsosejugal furrow straight; Notogaster surface covered with a reticulated pattern formed by a varying number of rounds, small chitinized tubercles; fourteen pairs of phylliform notogastral setae; the humeral region rounded and without triangular tubercle. Ventral surface with well-developed net-pattern. Epimeral setal formula: 3-1-2-3. Genito-anal setal formula: $4-1-2-3$. Adanal setae $a d_{1}$ and $a d_{2}$ phylliform, setae $\mathrm{ad}_{3}$ smooth.

Material examined: Turkey, Mersin, Erdemli, $36^{\circ} 40^{\prime} 104^{\prime} \mathrm{N}, 034^{\circ} 16^{\prime} 524^{\prime \prime} \mathrm{E}, 432 \mathrm{~m}$ a.s.l., 17 . V.2014, soil and litter from mixed forest, 18 exs (two of them were used for scanning electron microscopy).

Distribution in Turkey: Erzurum and Mersin provinces (Figure 2) (Ayyıldız 1988). Mersin province given in the present study constitutes a second locality record after Erzurum province for the species in Turkey.

\section{Austrocarabodes (Austrocarabodes) foliaceisetus} foliaceisetus Krivolutsky, 1971

Measurements: Body length: 600-632, body width: 312$318 \mu \mathrm{m}(\mathrm{n}=10)$.

Diagnosis (Figure 3): Prodorsum surface covered by irregular ridges. All dorsal setae phylliform. Lamellar 
setae inserted on distal lateral surface of lamellae; interlamellar setae originating close to inner margin of lamellae. Sensillus long, its distal part slightly granulated. Notogastral surface covered by welldeveloped round tubercles. The humeral region with triangular tubercle. Fourteen pairs of phylliform and dentate notogastral setae. Dorsosejugal furrow nearly straight. Ventral surface covered by net-pattern. All adanal setae phylliform and dentate. Epimeral setal formula: 3-1-3-3. Genito-anal setal formula: 4-1-2-3.
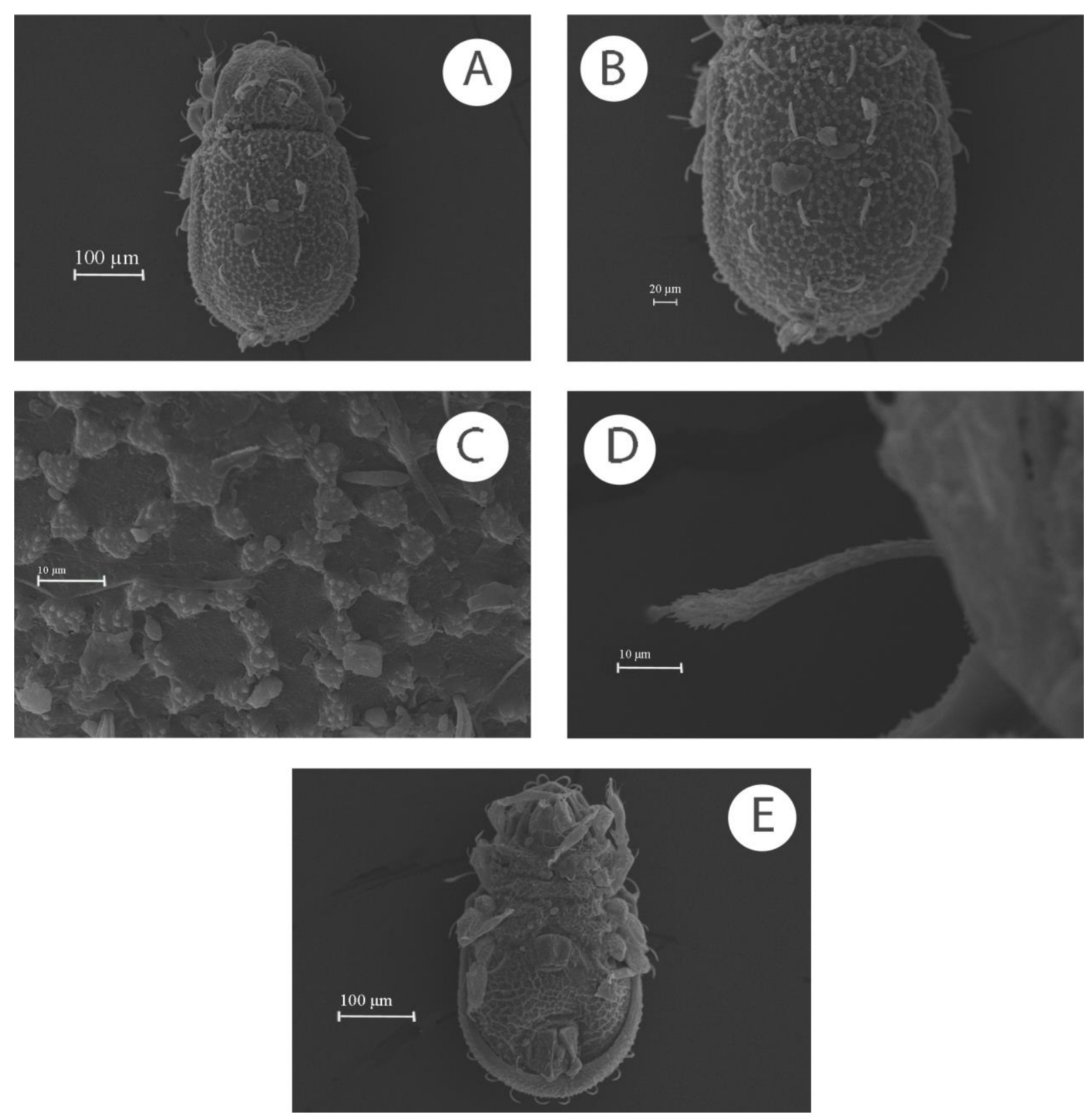

Figure 1. Austrocarabodes (Austrocarabodes) ensifer (Sellnick, 1931). A - dorsal view; B - notogaster; C - pattern in central part of notogaster; D - sensillus; E - ventral view.

Şekil 1. Austrocarabodes (Austrocarabodes) ensifer (Sellnick, 1931). A - sırttan görünüş; B - notogaster; Cnotogasterin orta bölgesi deseni; $D$ - sensillus; $E$ - karından görünüş.

Material examined: Turkey, Aksaray, Ihlara Valley, $38^{\circ} 15^{\prime} 30^{\prime} \mathrm{N}, 34^{\circ} 17^{\prime} 46^{\prime} \mathrm{E}, 1212 \mathrm{~m}$ a.s.l., 1.V.2017, litter and soil, 14 exs (one of them was used for scanning electron microscopy).

Distribution in Turkey: Aksaray province (Figure 2). It constitutes the first locality record for the species in Turkey.
Genus Carabodes C. L. Koch, 1835

Carabodes (Carabodes) labyrinthicus (Michael, 1879)

Measurements: Body length: 464-608, body width: 264$368 \mu \mathrm{m}(\mathrm{n}=10)$. 


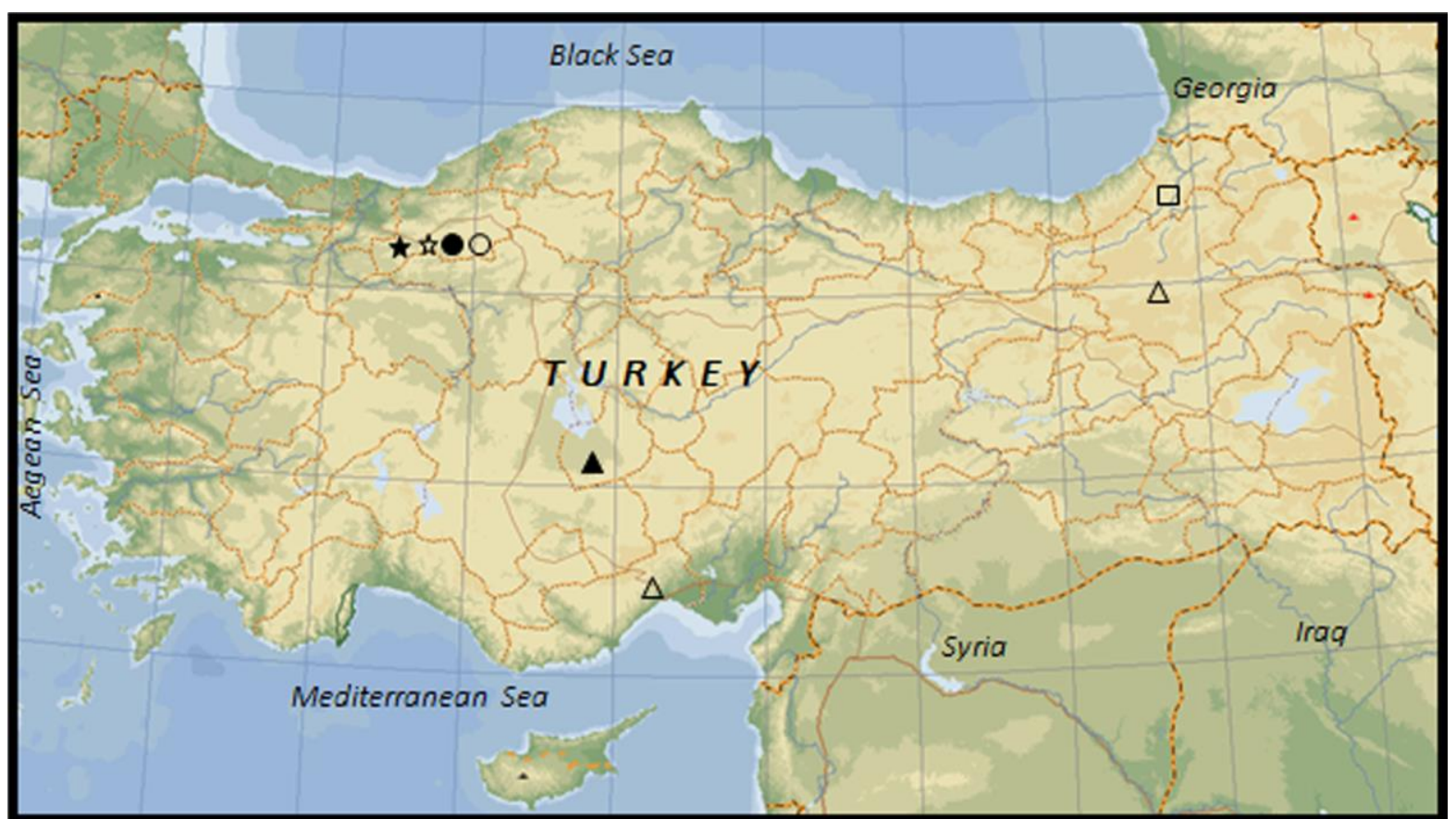

Figure 2. General map of Turkey showing locations of sampled populations. $\Delta^{-}$Austrocarabodes (A.) ensifer, $\mathbf{\Lambda}^{-} A$. (A.) foliaceisetus foliaceisetus, O-Carabodes (C.) labyrinthicus, - C. (C.) pirinensis, 口- C. (Flexa) djaparidzae, $\star$ - C. (C.) rugosior, - C. (Flexa) dubius.

Şekil 2. Örneklenen populasyonların lokalitelerini gösteren genel Türkiye haritası. $\Delta$-Austrocarabodes (A.) ensifer, $\mathbf{\Delta}-A$. (A.) foliaceisetus foliaceisetus, O-Carabodes (C.) labyrinthicus, $-C$. (C.) pirinensis, $\square-C$. (Flexa) djaparidzae, $\star$ - C. (C.) rugosior, - C. (Flexa) dubius.
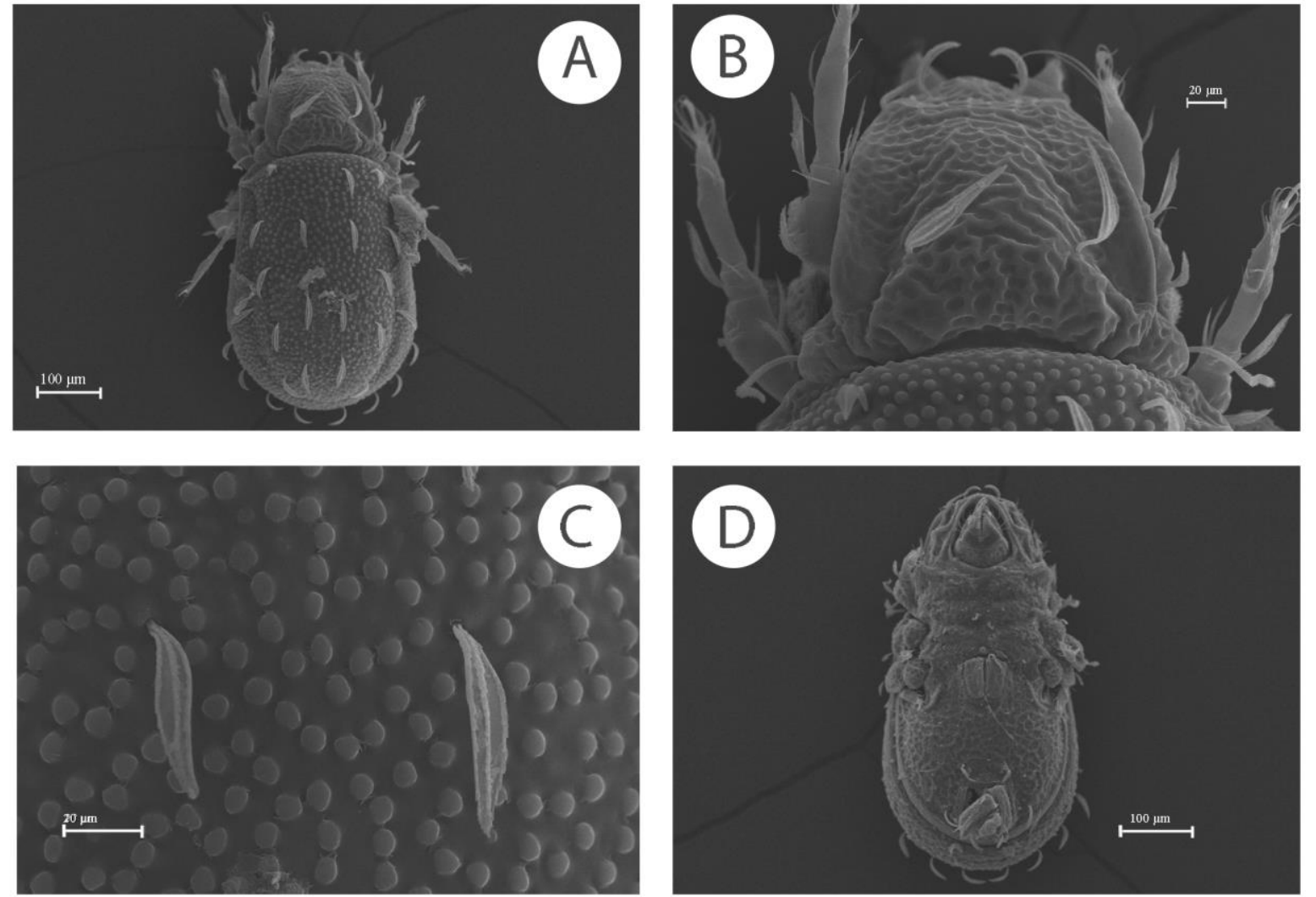

Figure 3. Austrocarabodes (Austrocarabodes) foliaceisetus foliaceisetus Krivolutsky, 1971. A - dorsal view; B prodorsum; C - pattern in central part of notogaster and the setae da; D - ventral view.

Şekil 3. Austrocarabodes (Austrocarabodes) foliaceisetus foliaceisetus Krivolutsky, 1971. A-sirttan görünüs; Bprodorsum; $C$-notogasterin orta bölgesi deseni ve da kıll; D - karından görünüş. 
Diagnosis (Figure 4): Rostral, lamellar and interlamellar setae setiform. Interlamellar region converging, with irregular ridges. Sensillus short clavate, directed laterally. Dorsosejugal furrow absent. Notogastral sculpture with joint tubercles. Ten pairs of baciliform notogastral setae. Setae $c_{2}$ in lateral position. Epimeral setal formula: 3-1-2-3. Genito-anal setal formula: 4-1-2-3.
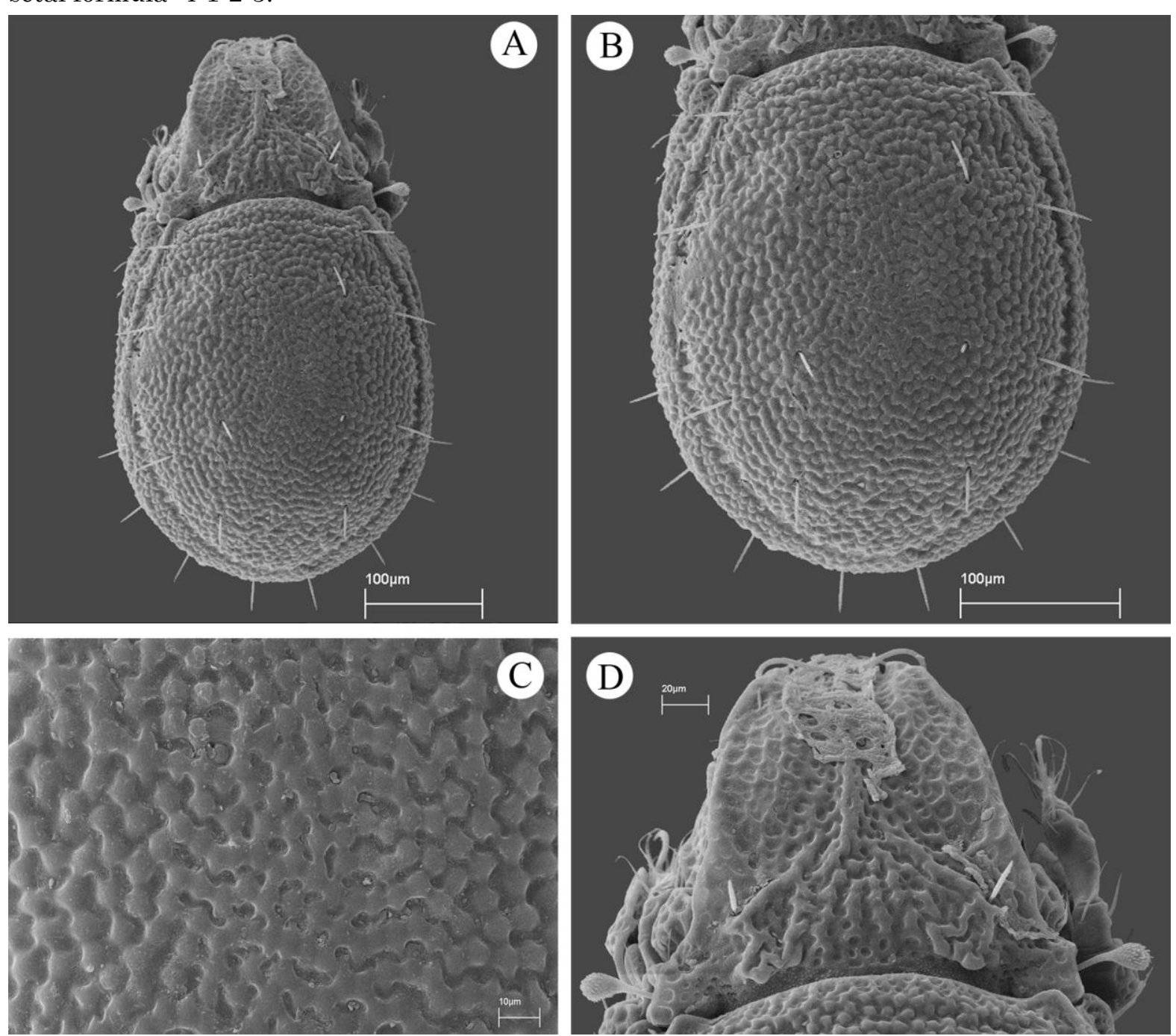

Figure 4. Carabodes (Carabodes) labyrinthicus (Michael, 1879). A - dorsal view; B - notogaster; C - notogastral pattern; D - prodorsum.

Şekil 4. Carabodes (Carabodes) labyrinthicus (Michael, 1879). A-sirttan görünüş; B-notogaster; C-notogaster deseni; $D$ - prodorsum.

\section{Carabodes (Carabodes) pirinensis Kunst, 1961}

Measurements: Body length: 504-560, body width: $272^{-}$ $320 \mu \mathrm{m}(\mathrm{n}=10)$.

Diagnosis (Figure 5): Interlamellar setae long, strong, slightly curved inside, inserted on the middle of the lamellae. Sensillus with a finger-shaped head. The interlamellar region separated from the rostrum by a transverse hump with eight- ten longitudinally running furrows. A semicircular chitin plate with two teeth on the basis of the prodorsum present.
Material examined: Turkey, Bolu, Gölcük lake side, $40^{\circ} 39^{\prime} 37^{\prime} \mathrm{N}, 31^{\circ} 37^{\prime} 38^{\prime \prime} \mathrm{E}, 1218 \mathrm{~m}$ a.s.l., 10.V.2008, soil and litter from mixed forest, 52 exs (one of them were prepared for scanning electron microscopy).

Distribution in Turkey: Bolu province (Figure 2). It constitutes the first locality record for the species in Turkey. 

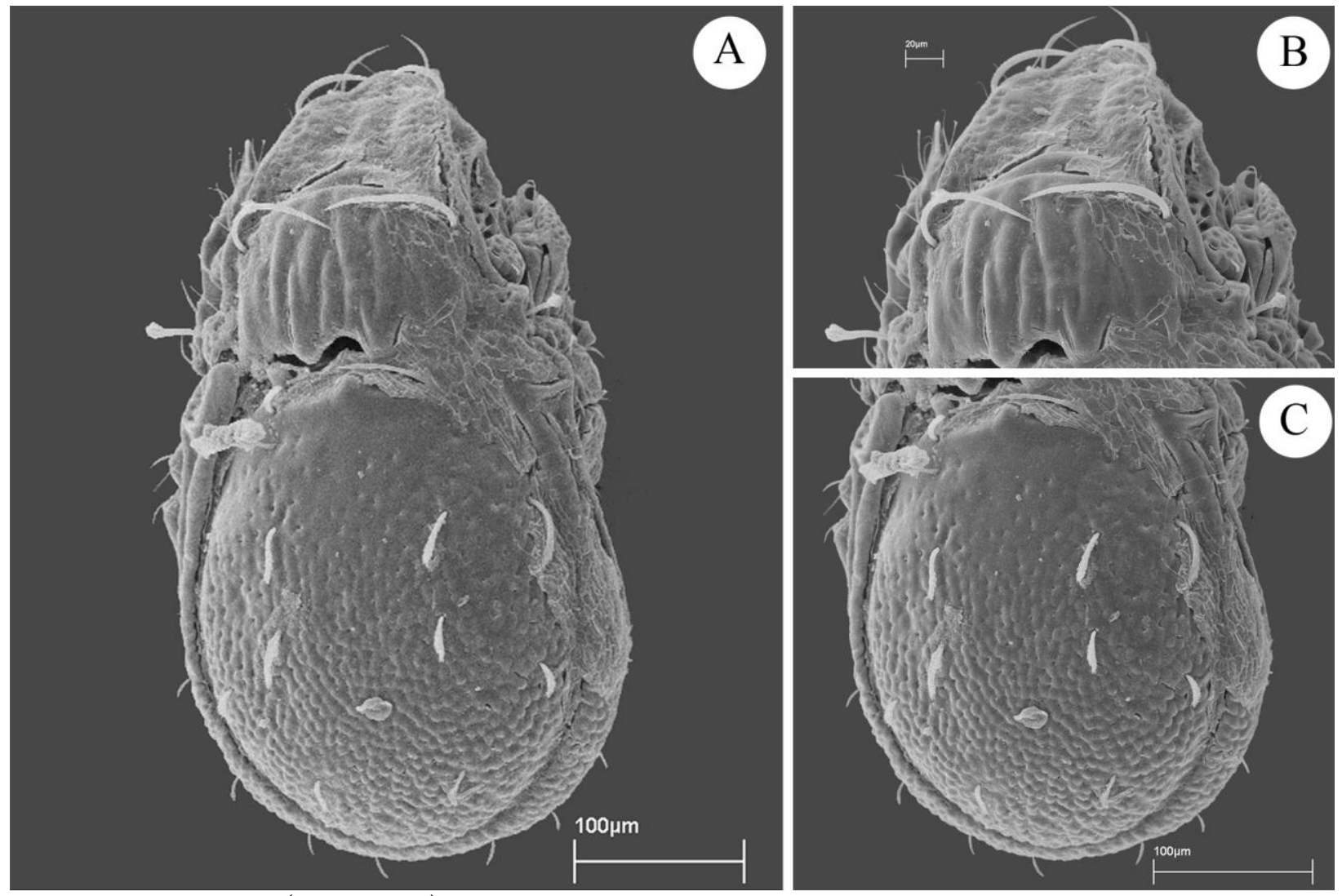

Figure 5. Carabodes (Carabodes) pirinensis Kunst, 1961. A - dorsal view; B - prodorsum; C - notogastral pattern. Şekil 5. Carabodes (Carabodes) pirinensis Kunst, 1961. A-sirttan görünüş; B-prodorsum; C-notogaster deseni.

Distribution in Turkey: Bolu province (Figure 2). It constitutes the first locality record for the species in Turkey.

\section{Carabodes (Carabodes) rugosior Berlese, 1916}

Measurements: Body length: 480-496, body width: 288$304 \mu \mathrm{m}(\mathrm{n}=3)$.

Diagnosis (Figure 6): Rostral setae smooth, curved inside. Setae in and le short and setiform. Sensillus slender, ciliate distally divided into finger shaped and widened. Dorsosejugal furrow absent. Interlamellar region with two protuberances. Notogastral sculpture with a strong longitudinal mid-ridge, next to it irregular narrower longitudinal and transverse ridges. Ten pairs of short and setiform notogastral setae. Setae $c_{2}$ inserted near humeral region. Epimeral setal formula: 3-1-2-3. Genito-anal setal formula: 4-1-2-3.

Material examined: Turkey, Bolu, Gölcük lake side, $40^{\circ} 39^{\prime} 37^{\prime} \mathrm{N}, 31^{\circ} 37^{\prime} 38^{\prime} \mathrm{E}$, $1218 \mathrm{~m}$ a.s.l., 10.V.2008, soil and litter from mixed forest, 4 exs (one of them were mounted on aluminum stubs and gold-coated for scanning electron microscopy).

Distribution in Turkey: Bolu province (Figure 2). It constitutes the first locality record for the species in Turkey.
Carabodes (Flexa) djaparidzae Murvanidze and Weigmann, 2007

Measurements: Body length: 496-544, body width: 288$320 \mu \mathrm{m}(\mathrm{n}=7)$.

Diagnosis (Figure 7): Prodorsum surface covered by irregular ridges. Rostral and lamellar setae smooth, curved inside. Interlamellar setae long, slightly granulated, positioned on the lamellae and curved inside. Sensillus distally split into fingers. Notogaster reticulate pattern represented by generally rounded cells. Ten pairs of notogastral setae present; setae $c_{2}$ long, erect, directed forward, other setae phylliform. Dorsosejugal furrow nearly broad. Epimeral setal formula: 3-1-3-3. Genito-anal setal formula: 4-1-2-3.

Material examined: Turkey, Artvin, Yusufeli, Çevreli village, , $40^{\circ} 46^{\prime} 07^{\prime} \mathrm{N}, 41^{\circ} 2^{\prime} 37^{\prime} \mathrm{E}, 1149 \mathrm{~m}$ a.s.l., 17.VIII.1993, litter and soil underlying Pinus sp. in a mixed forest, 8 exs (one of them were prepared for scanning electron microscopy).

Distribution in Turkey: Artvin province (Figure 2). It constitutes the first locality record for the species in Turkey.

Carabodes (Flexa) dubius Kulijev, 1968

Measurements: Body length: 396, body width: $225 \mu \mathrm{m}$ $(\mathrm{n}=1)$. 

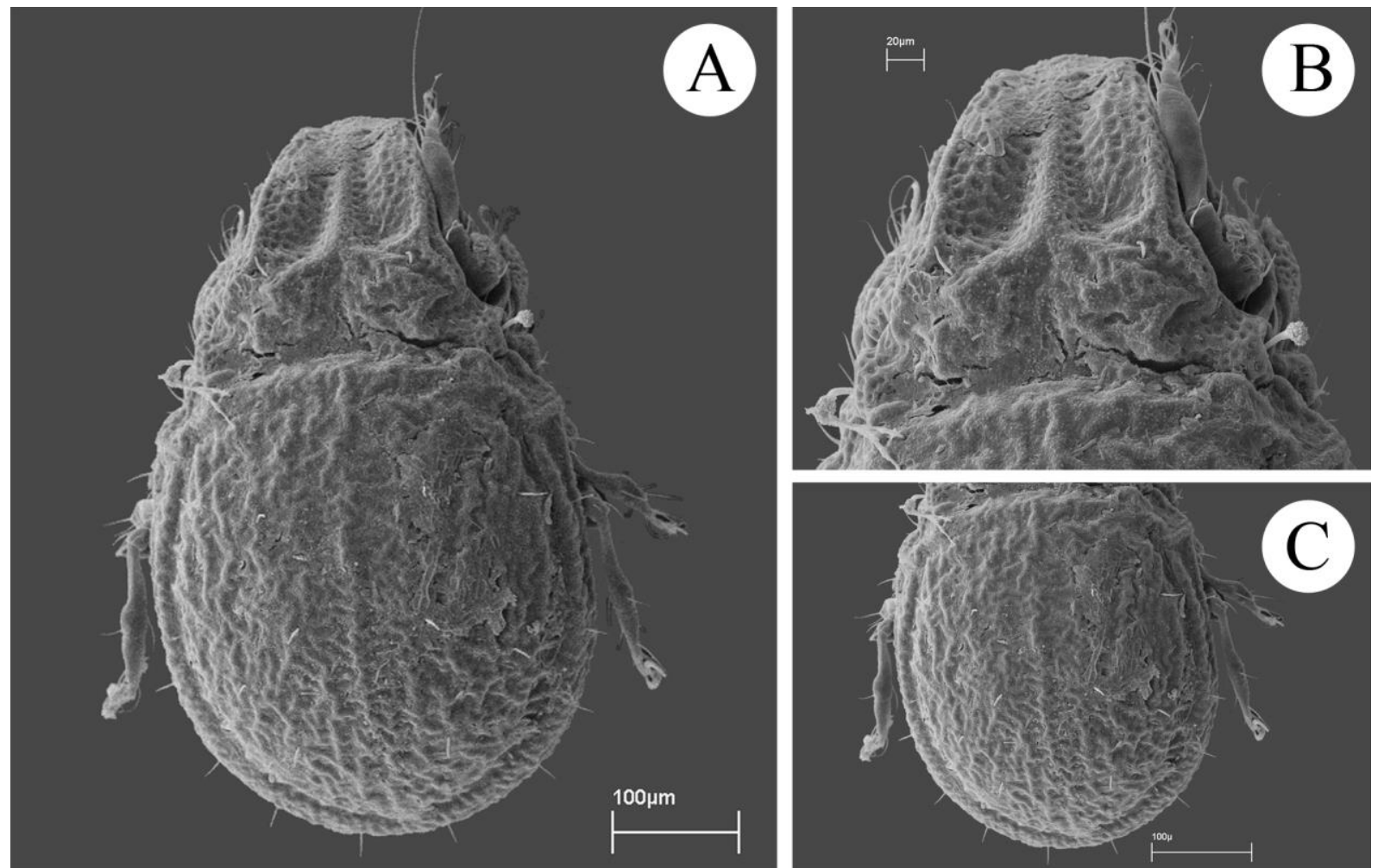

Figure 6. Carabodes (Carabodes) rugosior Berlese, 1916. A - dorsal view; B - prodorsum; C - notogastral pattern. Şekil 6. Carabodes (Carabodes) rugosior Berlese, 1916. A - sirttan görünüs,; B-prodorsum; C-notogaster deseni.

Diagnosis (Figure 8): Prodorsal cerotegument with netlike pattern anteriorly. Lamellar setae curved inside, with ciliate. Interlamellar setae long, strong, slightly curved inside. Sensillus with a finger-shaped head. Interlamellar region with several short longitudinal grooves in two rows. Dorsosejugal furrow wide. Setae $c_{2}$ bacilliform long, strong, erect, directed forward. Notogastral sculpture with areolae and pustulate. Ten pairs of notogastral setae narrow phylliform, barbed throughout length, inserted submarginally. Setae $\mathrm{p}^{-}$ and $\mathrm{r}^{-}$series smaller than the others Epimeral setal formula: 3-1-2-3. Genito-anal setal formula: 4-1-2-3.

Material examined: Turkey, Bolu Province, Gölcük lake side, , $40^{\circ} 39^{\prime} 37^{\prime} \mathrm{N}, 31^{\circ} 37^{\prime} 38^{\prime \prime} \mathrm{E}, 1218 \mathrm{~m}$ a.s.l., 10.V.2008, soil and litter from mixed forest, 1 ex (one specimen prepared for scanning electron microscopy).

Distribution in Turkey: Bolu province (Figure 2). It constitutes the first locality record for the species in Turkey.

\section{DISCUSSION}

The results obtained for each taxon are discussed from the taxonomic, ecological and zoogeographical view, below.

Austrocarabodes (Austrocarabodes) ensifer (Sellnick, 1931)

$\begin{array}{lll}\text { Taxonomical } & \text { remarks and } & \text { comparison: } \\ \text { Austrocarabodes } & \text { (Austrocarabodes) ensifer was }\end{array}$

described by Sellnick (1931) from Greece (Ionian Islands). This species can be distinguished from congeners by the presence of prodorsum with irregular polygonous pattern; sensillus with setulae and rounded in the distal part; rounded humeral processes; reticulate notogastral pattern formed by a varying number of round, small chitinized tubercles; phylliform notogastral setae and adanal setae ( $\mathrm{ad}_{1}$ and $\mathrm{ad}_{2}$ ); net-like pattern in ventral side (Sellnick 1931, Pérez-Íñigo 1971, 1997, Ayyıldız 1988, Murvanidze and Weigmann 2007). The known body size for this species is in the range of 525-550/ 288-340 $\mu \mathrm{m}$ (Sellnick 1931, Pérez-Íñigo 1971, 1997, Bulanova- Zakhvatkina 1975, Ayylddz 1988). The dimensions of the Turkish specimens $(464-520 \times 240-288 \mu \mathrm{m})$ are smaller than the previously given. Humeral processes in the Turkish specimens are rounded and without tubercles, which are in concordance with the description of Bulanova-Zakhvatkina (1975) and Ayyıldız (1988) but the chitinized triangular tubercles have been shown in illustrations and descriptions by Pérez-Íñigo (1971, 1997), Mahunka (1986) and Murvanidze and Weigmann (2007). In terms of the other morphological features, the Turkish specimens are in conformity with the descriptions given by the various authors (Sellnick 1931, Pérez-Íñigo 1971, 1997, Bulanova-Zakhvatkina 1975, Mahunka 1986, Ayyıldız 1988, Murvanidze and Weigmann 2007). 

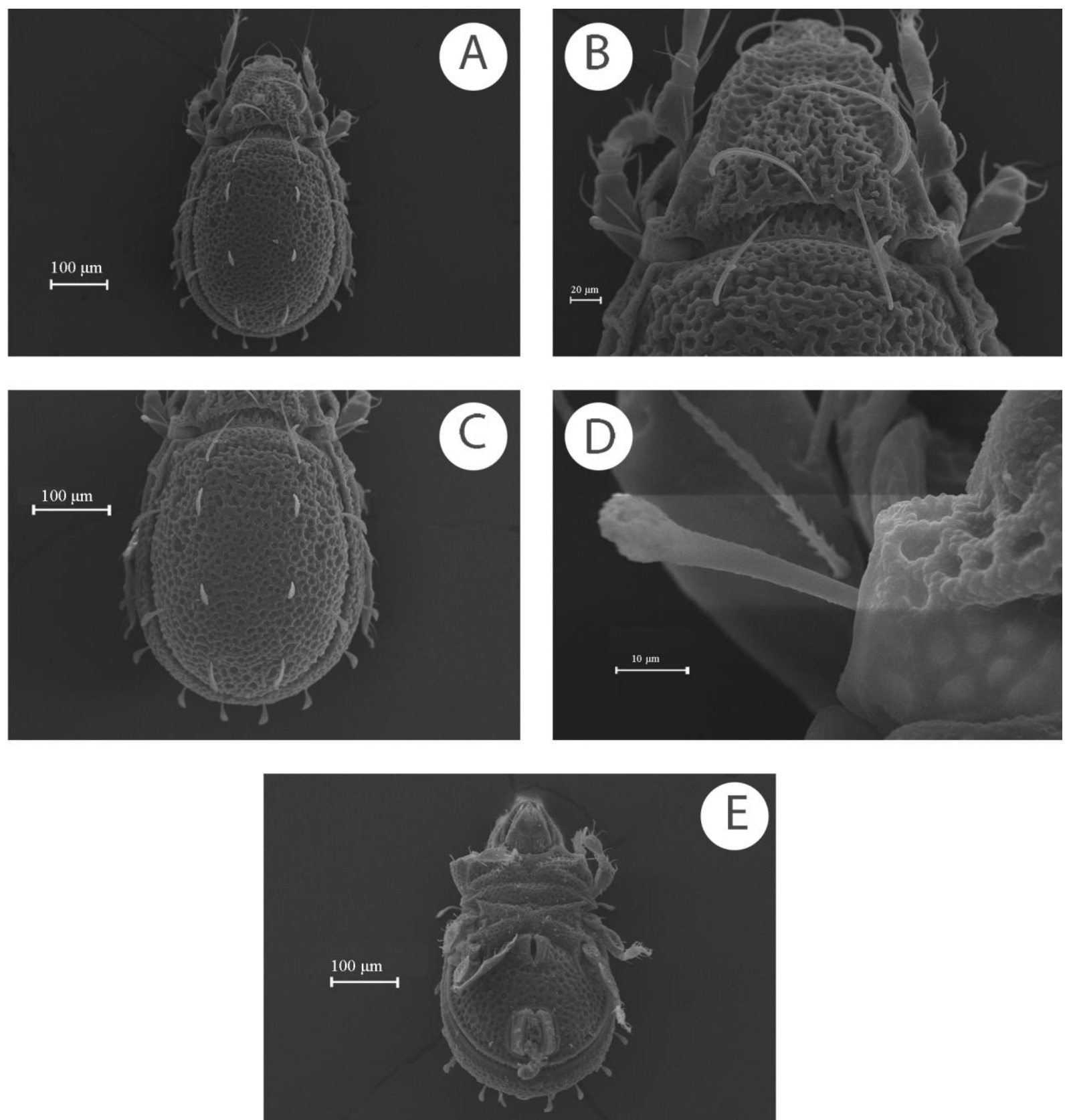

Figure 7. Carabodes (Flexa) djaparidzae Murvanidze and Weigmann, 2007. A - dorsal view; B - prodorsum; C notogastral pattern; D - sensillus; E - ventral view.

Şekil 7. Carabodes (Flexa) djaparidzae Murvanidze ve Weigmann, 2007. A - sırttan görünüş; B - prodorsum; Cnotogaster deseni; D-sensillus; $E$ - karından görünüş.

Distribution and Ecology: This species is presently from Southern Palearctic (Mediterranean and CentralWestern Asia) (Subías 2004). It is distributed in Greece, Spain, Portugal, Russia (Lower Volga, Pamir), Georgia and Turkey (Sellnick 1931, BulanovaZakhvatkina 1975, Barjadze and Murvanidze 2016). It was previously reported by Ayyıldız (1988) in Turkey. This species has been found in semi-desert soil of the Lower Volga region of Russia (BulanovaZakhvatkina 1975). Ayyıldız (1988) reported that it was collected from the fruit garden, arid soils and pine woods. According to Pérez-Ínigo (1997), this species is typical of the Mediterranean scrubland and has almost always been found near the coast. Specimens belonging to this species have been extracted from artificial arid woodland and mixed forest in Georgia (Barjadze and Murvanidze 2016). Murvanidze and Mumladze (2016) reported that this species lives in forest soils. We found this species in soil and litter collected from a mixed forest. The occurrence analysis of Austrocarabodes (Austrocarabodes) ensifer shows that its preferred substrate types as soil and litter.

A. (A.) foliaceisetus foliaceisetus Krivolutzky, 1971 

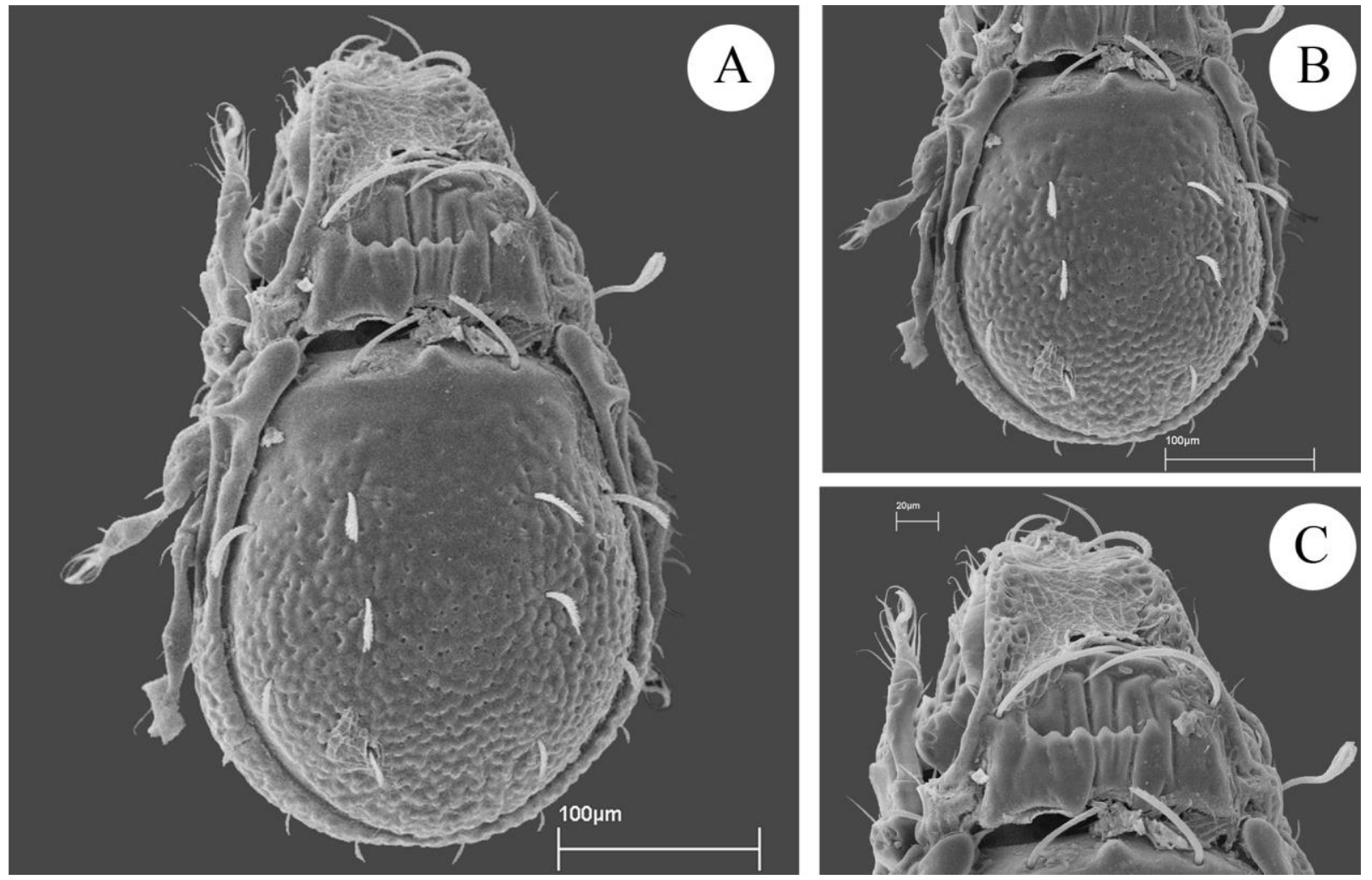

Figure 8. Carabodes (Flexa) dubius Kulijev, 1968. A - dorsal view; B - notogaster; C - prodorsum. Şekil 8. Carabodes (Flexa) dubius Kulijev, 1968. A-sirttan görünüş; B-notogaster; $C$ - prodorsum.

Taxonomical remarks and comparison: $A$. (A.) foliaceisetus foliaceisetus Krivolutzky, 1971 was firstly described from Eastern Kirgizia. This subspecies can be distinguished from congeners by the presence of prodorsum with irregular ridge pattern; rounded humeral processes with triangular tubercles; notogastral pattern formed by round tubercles; phylliform notogastral and adanal setae ( $\left.\mathrm{ad}_{1} \mathrm{ad}_{2} \mathrm{ad} \mathrm{d}_{3}\right)$; net-like pattern in ventral side (Krivolutzky 1971, Murvanidze and Mumladze 2016).

The body size in the original description of this subspecies is 602/324 $\mu \mathrm{m}$ (Krivolutzky 1971). The dimensions of the Turkish specimens (600-632 x 312 $318 \mu \mathrm{m})$ are in conformity with the Kirgizia nominal subspecies. Humeral processes in the Turkish specimens are rounded and with tubercles, but the chitinized triangular tubercles have not been shown in the original illustration and description given by Krivolutzky (1971). Apart from this difference, in terms of the other morphological features, the Turkish specimens are in conformity with the original description (Krivolutzky, 1971).

Distribution and Ecology: This sub-species is presently known from Southern Palearctic (Eastern Mediterranean and Central-Western Asia) (Subías 2004). This sub-species was recorded also in Iran (Rahgozar et al. 2019). Turkey is the third locality record outside its type locality (Kirgizia) and Iran.
Krivolutzky (1971) reported that this species was found in the mountains of Central Asia but did not provide any information about the type of substrate. This subspecies was found in the apple orchards in Iran (Rahgozar et al. 2019). We found in litter and soil in a dry valley. Literature data show that it preferred different habitat types as alpine, valley and orchards.

Carabodes (Carabodes) labyrinthicus (Michael, 1879)

Taxonomical remarks and comparison: This species can be distinguished from congeners by the presence of clavate sensillus; notogastral pattern with joint tubercles; bacilliform apically pointed notogastral setae (Weigmann 2006, Murvanidze 2008). The body length for the species is given as $430-580 \mu \mathrm{m}$ by Weigmann (2006) and Murvanidze (2008). In this regard, the Turkish specimens (464-608x 264-368 $\mu \mathrm{m}$ ) are in the range of the dimensions of the known specimens. The Turkish specimens closely resemble all the features given by Weigmann (2006) and Murvanidze (2008) for this species. This is the first record from Turkey.

Distribution and Ecology: This species is presently known from Holarctic region and Mexico (Subías 2004). It is a new record for Turkey fauna. C. (C.) labyrinthicus is found in the arboreal fruiting bodies of the fungus Daldinia concentrica; the canopy of beech, oak, larch and spruce in a mixed temperate forest; the feathers of birds; the anthill; forest soils, moss, litter, 
tree bark and canopy (Hingley 1971, Wunderle 1992, Krivolutzky and Lebedeva 2004, Sobek et al. 2008, Mahunka and Mahunka-Papp 2009, Murvanidze and Mumladze 2016). Schneider (2005) placed it in the phycophage/fungivore feeding category. According to Schatz (2016), it is a euryoecious species, also arboricolous, muscicolous and silvicolous. Also, this species is found in arctic tundra of Alaska and northern Canada (Reeves and Behan-Pelletier 1998). According to Weigmann (2006) it lives in acidic, differently moist forest soils; in moss cushions and tree barks. Subías (1977) confirms his preference for mosses on rocks. Rajski (1968) considers it as a kind of forest residence. It prefers acidic soil and medium humidity (Pérez-Íñigo 1997).

It is known from the literature to be preferred inhabitants of saxicolous or arboricolous mosses and lichens (Materna 2000). We found it in soil and litter from mixed forest. Literature data show that it is tolerant to a wide range of environmental conditions and widely distributed.

\section{C. (C.) pirinensis Kunts, 1961}

Taxonomical remarks and comparison: This species can be distinguished from congeners by the presence of the interlamellar region separated from the rostrum by a transverse hump with eight- ten longitudinally running furrows; a semicircular chitin plate with two teeth on the basis of the prodorsum; long, strong, smooth, slightly curved inside interlamellar setae, inserted on the middle of the lamellae (Kunst 1961). The body dimension for the type specimens is in the range of 570-604 x 330-370 (Kunst 1961). The Turkish specimens $(504-560 \times 272-320 \mu \mathrm{m})$ are smaller than the dimensions of the type specimens. The notogastral setae $p_{S_{1}-3}$ and $r_{3}$ in the Turkish specimens are bacilliform with dentate, but all notogastral setae have been shown as phylliform in the original illustration and description given by Kunts (1961). Apart from this difference, in terms of the other morphological features, the Turkish specimens are in conformity with the original description (Kunst 1961). This is the first record from Turkey.

Distribution and Ecology: Carabodes (Carabodes) pirinensis was described by Kunst (1961) from Bulgaria. He found this species in dry litter layer of forest. We found it in soil and litter from mixed forest. Turkey is first locality record outside its type locality (Bulgaria). In terms of ecology it can be considered a typical inhabitant of forest litter and soil.

\section{C. (C.) rugosior Berlese, 1916}

Taxonomical remarks and comparison: This species can be distinguished from congeners by the presence of prodorsum with two protuberances in posterior part; notogastral sculpture with a strong longitudinal midridge, next to it irregular narrower longitudinal and transverse ridges; ten pairs of short and setiform notogastral setae (Reeves and Behan-Pelletier 1998, Weigmann 2006, Murvanidze 2008). The body length for the species is given as 520-650 $\mu \mathrm{m}$ (Weigmann 2006, Murvanidze 2008). The Turkish specimens (480$496 \times 288-304 \mu \mathrm{m})$ are smaller than the dimensions of the known specimens (Reeves and Behan-Pelletier 1998, Weigmann 2006, Murvanidze 2008). The Turkish specimens closely resemble all the features given by Weigmann (2006) and Murvanidze (2008) for this species. This is the first record from Turkey.

Distribution and Ecology: Holarctic (Palearctic and northern Nearctic) (Reeves and Behan-Pelletier 1998, Subías 2004, Murvanidze 2008, Mahunka and Mahunka Papp 2009, Kagainis 2010, Hågvar et al. 2014). Weigmann (2006) found it in forest litter and on tree stumps. Murvanidze and Mumladze (2016) reported this species from forest soils. In Latvia, this species is found from coniferous forest soil (Kagainis 2010, Hågvar et al. 2014). According to Schatz (2016), it is a silvicolous species. We found this species in soil and litter from mixed forest. In terms of ecology it can be considered a typical inhabitant of forest litter and soil.

C. (Flexa) djaparidzae Murvanidze and Weigmann, 2007,

Taxonomical remarks and comparison: This species was described by Murvanidze and Weigmann (2007) from Georgia. It can be distinguished from congeners by the presence of reticulate notogastral pattern represented by generally rounded cells; long, curved inside interlamellar setae; sensillus with distally finger-shaped head; phylliform notogastral (except setae $c_{2}$ long and erect) and adanal setae (setae $a d_{1}$ and $a d_{2}$ ). The body length and width for the species is given as 510 and $260 \mu \mathrm{m}$, respectively (Murvanidze and Weigmann 2007). In this regard, the dimensions of the type specimen are in the range of the dimensions of the Turkish specimens (496-544 x 288-320 $\mu \mathrm{m})$. Murvanidze and Weigmann (2007) stated that notogaster has flower shaped pattern formed by bright foveolae surrounded by chitinized tubercles. Their drawings match the images that we observed in SEM. However, it does not look like a flower-shaped pattern. This can be due to difference in SEM and the light microscopic examination. In general, the Turkish specimens are in conformity with the original description given by Murvanidze and Weigmann (2007). This is the first record from Turkey.

Distribution and Ecology: Caucasus (Subías 2004). Carabodes (Flexa) djaparidzae Murvanidze and Weigmann, 2007 was firstly described from Georgia. Up to now this species was known only from the type locality. Turkey is second locality record. This species was found in soil of a Carpinus forest; moss in Populus tremula-Pinus forest; understory with different grasses in Georgia. We found this species in litter and soil underlying Pinus sp. in a mixed forest. From the 
available data, it is understood that this species prefers forest floor.

\section{C. (Flexa) dubius Kulijev, 1968}

Taxonomical remarks and comparison: This species was described by Kulijev (1968) from Azerbaijan. It can be distinguished from congeners by the presence of interlamellar region with several short longitudinal grooves in two rows; setae $c_{2}$ bacilliform long, strong, erect, directed forward; nine pairs of notogastral setae narrow phylliform, barbed throughout length, inserted submarginally. The body length for the species is given as $420-517 \mu \mathrm{m}$ by Murvanidze, (2008), 422-474 by Kulijev (1977). The Turkish specimens (396 x $225 \mu \mathrm{m})$ are smaller than the dimensions of the known specimens. The Turkish specimens closely resemble all the features given by Kulijev (1977) and Murvanidze (2008) for this species. This is the first record from Turkey.

Distribution and Ecology: Carabodes (Flexa) dubius is distributed in Caucasus (Azerbaijan and Georgia) (Subías 2004, Murvanidze 2008). It collected from moss on rock wall of a canyon and in mountain forest soils (Murvanidze and Mumladze 2016). We found it in soil and litter from mixed forest.

\section{CONCLUSION}

The present study added six new records of the genus Carabodes to the oribatid fauna of Turkey. For Carabodes (Carabodes) pirinensis Kunst, 1961 and Carabodes (Flexa) djaparidzae Murvanidze and Weigmann, 2007 Turkey are the first locality record outside their type localities Bulgaria and Georgia, respectively. The taxa identified in this study have a Palearctic distribution. They are specifically distributed in the European and Mediterranean subregions of the Palearctic region. This is consistent with the fact that Turkey is located on cross section of the Boreal, Euro-Siberian, Irano-Turan and Mediterranean elements. In general, the species of Carabodidae prefer more or less humid forest habitats and are rare in non-humid environments.

\section{ACKNOWLEDGEMENTS}

Some of the data in this study were presented as poster in $8^{\text {th }}$ Symposium of the European Association of Acarologists under the title of "New records of the genus Carabodes (Acari, Oribatida, Carabodidae) from Turkey ". We are grateful to Dr. M. Murvanidze (Tbilisi, Georgia), for their valuable comments. We would also like to thank Erciyes University's Nanotechnology Research and Implementation Center and Technology Research and Implementation Center for their assistance in SEM imaging.

\section{Researchers Contribution Rate Declaration Summary}

The authors declare that they have contributed equally to the article.

\section{Conflicts of Interest Statement}

None of the authors had any financial or personal relationships with other individuals or organizations that might inappropriately influence their work during the submission process.

\section{REFERENCES}

Ay Y, Ayyıldız N 2019a. Investigations on Oppioid Oribatid Mites of Amanos Mountains (Turkey). Plant Protection Bulletin, 59(3): 15-23.

Ay Y, Ayyıldız N 2019b. New Locality Records of Oppioid Oribatid Mites (Acari, Oribatida, Oppioidea) from the Amanos Mountains (Turkey). KSÜ Tarım ve Doğa Dergisi, 22(6): 905-915.

Ayyıldız N 1988. Systematic Investigations on the Oribatid Mites (Acari: Oribatida) of the Erzurum Plain. II. Higher Oribatids. Doğa- Turkish Journal of Zoology, 12(2): 131-144.

Ayyıldız N 1989. Mites of the Family Oppiidae (Acari, Oribatida) from Turkey. Journal of Natural History, 23(6): 1373-1379.

Ayyıldız N, Luxton M 1989a. New and Unrecorded Oribatid Mites (Acari) from Turkey. Zoologischer Anzeiger, 222(5/6): 294-300.

Ayyıldız N, Luxton M 1989b. Epimerellidae (Acari, Oribatida) A New Mite Family. Journal of Natural History, 23(6): 1381-1386.

Ayyıldız N, Luxton M 1990. The Genus Cosmochthonius Berlese, 1910 (Oribatida, Cosmochthoniidae). Acarologia, 31(3): 279-284.

Ayyıldız N, Subías LS, Baran Ş 2016. Review of the Family Perlohmanniidae (Acari: Oribatida) with Description of a New Species from Turkey. Biologia, 71(3): 323-327.

Baran Ş, Ayyıldız N 2008. Contribution to the Quadroppiidae (Acari, Oribatida) Fauna of Turkey. Turkish Journal of Zoology, 32(2): 131-135.

Baran Ş, Ayyıldız N, Kence A 2012. Two New Species and a New Record of Oppioid Mites (Acari: Oribatida) from Turkey. Pakistan Journal of Zoology, 44(3): 777-785.

Baran Ş, Bezci T, Ayyıldız N 2018. Supplementary Checklist of Oribatid Mites (Acari) from Turkey. Munis Entomology and Zoology, 13(1): 91-97.

Baran S, Toluk A, Ayyildiz N 2009. Mites of the Genus Quadroppia Jacot, 1939 (Acari: Oribatida; Quadroppiidae) from Turkey, with Zoogeographical Remarks. Entomological News, 120(3): 240-252.

Barjadze S, Murvanidze M 2016. New Records of Springtails (Collembola: Entomobryomorpha) and Oribatid Mites (Acari: Oribatida) in Georgia. Turkish Journal of Zoology, 40(1): 117-119.

Bulanova-Zakhvatkina EM 1975. Nadsemeistvo Carabodoidea Dubinin, 1954. (Opredelitel' Obitayushchikh v Pochve Kleshchey: Sarcoptiformes, Istadel'stwo Nauka, Moscow: Eds. 
Ghilarov MS, Krivolutzky DA) 184-190.

Demirsoy A 1999. Genel ve Türkiye Zoocoğrafyası "Hayvan Coğrafyası". Üçüncü Baskı. Meteksan AŞ, Ankara, pp. 965.

Gergócs V, Hufnagel L 2009. Application of Oribatid Mites as Indicators (Review). Applied Ecology and Environmental Research, 7(1): 79-98.

Hågvar S, Amundsen T, Økland B 2014. Mites of the Genus Carabodes (Acari, Oribatida) in Norwegian Coniferous Forests: Occurrence in Different Soils, Vegetation Types and Polypore Hosts. Scandinavian Journal of Forest Research, 29(7): 629-638.

Hingley MR 1971. The Ascomycete Fungus, Daldinia concentrica as a Habitat for Animals. Journal of Animal Ecology, 40(1): 17-32.

Kagainis U 2010. Carabodes rugosior Berlese, 1916 and $C$. subarcticus Trägardh, 1902 - New Species of Oribatid Mites (Acari: Oribatida: Carabodidae) for Fauna of Latvia, with Brief Discussion of Their Microscoping. Latvijas Entomologs, 48: 115-117.

Krivolutzky DA 1971. Some New Oribatoid Mites from Eastern Kirgisia. Zoologicheskii Zhurnal, 50(6): 939-942.

Krivolutzky DA, Lebedeva NV 2004. Oribatid Mites (Oribatei, Acariformes) in Bird Feathers: NonPasserines. Acta Zoologica Lituanica, 14: 26-47.

Kulijev KA 1977. Flexa Kulijev nov. gen. Typovoi Carabodes dubius Kulijev, 1968 Semeistvo Carabodidae C. L. Koch, 1837. Doklady Akademii Nauk Azerbaijan SSR, 33: 64-67.

Kunst M 1961. Bulgarische Oribatiden IV. (Acari: Oribatei). Acta Universitatis Carolinae - Biologia, 8: 151-183.

Mahunka S 1986. A Survey of the Family Carabodidae C.L. Koch, 1836 (Acari: Oribatida). Acta Zoologica Academiae Scientiarum Hungaricae, 32: 73-135.

Mahunka S, Mahunka-Papp L 2009. Oribatids from Switzerland X (Acari: Oribatida: Carabodidae) (Acarologica Genavensia C). Contributions to Natural History, 12: 931-949.

Materna J 2000. Oribatid Communities (Acari: Oribatida) Inhabiting Saxicolous Mosses and Lichens in the Krkonoše Mts. (Czech Republic). Pedobiologia, 44: 40-62.

Murvanidze M 2008. Checklist and Key to Species of Carabodes (Acari, Oribatida, Carabodidae) of the Caucasian Region with Description of a New Species. Acarina, 16(2): 177-186.

Murvanidze M, Mumladze L 2016. Annotated Checklist of Georgian Oribatid Mites. Zootaxa, 4089(1): 1-81.

Murvanidze M, Weigmann G 2007. New Carabodidae of Georgia. Tijdschrift voor Entomologie, 150: 193200.

Norton RA, Behan-Pelletier VM 2009. Suborder Oribatida. (A Manual of Acarology. 3rd ed. Texas
Tech University Press, Texas: Eds. Krantz GW, Walter DE) 430-564.

Per S, Ayyıldız N 2005. Erciyes Dağının (Kayseri) Epifitik Oribatid Akarları Üzerine Sistematik Araştırmalar- II. Çankaya Üniversitesi FenEdebiyat Fakültesi, Journal of Arts and Sciences, 3: 95-106.

Pérez-Iñigo C 1971. Acaros Oribatidos de Suelos de Espana peninsular e Islas Baleares (Acari, Oribatei). Parte 3. Eos, Revista Espaniola de Entomologia, 46: 263-350.

Pérez-Ínigo C 1997. Acari, Oribatei, Gymnonota I. (Fauna Ibérica, vol. 9. Museo Nacional de Ciencias Naturales, CSIC, Madrid: Eds. Ramos MA et al.) pp. 374.

Rahgozar M, Irani-Nejad KH, Zargaran MR, Saboori A 2019. Biodiversity and Species Richness of Oribatid Mites (Acari: Oribatida) in Orchards of East Azerbaijan Province, Iran. Persian Journal of Acarology, 8(2): 147-159.

Rajski A 1968. Autecological-Zoogeographical Analysis of Moss Mites (Acari, Oribatei) on the Basis of Fauna in the Poznan Environs. Part II. Fragmenta Faunistica, 14(12): 277-405.

Reeves RM, Behan-Pelletier V 1998. The Genus Carabodes (Acari: Oribatida: Carabodidae) of North America, with Descriptions of New Western Species. Canadian Journal of Zoology, 76: 18981921.

Schatz H 2016. Oribatid Mites (Acari, Oribatida) from the Biodiversity Days in South Tyrol (Prov. Bolzano, Italy). Gredleriana, 16: 113-132.

Schneider K 2005. Feeding Biology and Diversity of Oribatid Mites (Oribatida, Acari). Technical University, Darmstadt, PhD Thesis, pp. 115.

Schuppenhauer MM, Lehmitz R, Xylander WER 2019. Slow-Moving Soil Organisms on a Water Highway: Aquatic Dispersal and Survival Potential of Oribatida and Collembola in Running Water. Movement Ecology, 7: 20.

Sellnick M 1931. Acari, In: Beier M. Zoologische Forschungsreise nach den Jonischen Inseln und dem Peloponnes. XVI. Acari. Sitzungsberichte der Akademie der Wissenschaften mathematischnaturwissenschaftliche Klasse, 140: 693-776.

Sobek S, Kampichler C, Weigmann G 2008. Oribatid Mites (Acari: Oribatida) in the Canopy of a Central European Mixed Forest: Species Richness and Species Similarity Between Tree Species and Habitat Types. (Canopy Arthropod Research in Europe, Nuremberg, Bioform entomology: Eds. Floren A, Schmidl J) 339-354.

Subías LS 1977. Taxonomía y Ecología de los Oribátidos Saxícolas y Arborícolas de la Sierra de Guadarrama (Acarida, Oribatida). Universidad Complutense de Madrid, Spain, PhD Thesis, pp. 379.

Subías LS 2004. Listado Sistemático, Sinonímico y 
Biogeográfico de los Ácaros Oribátidos (Acariformes, Oribatida) del Mundo (1758-2002) (excepto fósiles), 14 actualización. Graellsia, 60 (núm. extr.): 3-305.

Susyal B, Ayyildiz N, Baran Ş 2018. A New Species of Eupterotegaeus (Acari, Oribatida, Compactozetidae) from Turkey. Entomological News, 128 (1): 65-71.

Toluk A 2016. A New Species of the Genus Rhinoppia (Acari, Oribatida, Oppiidae) from Turkey. Acarologia, 56(1): 91-98.

Toluk A, Ayyıldız N 2009a. Two New Species of the Genus Quadroppia (Acari: Oribatida:
Quadroppiidae) from Turkey. Biologia, 64(5): 930936.

Toluk A, Ayyıldız N 2009b. Three New Species of Oppiidae from Turkey (Acari: Oribatida). Zootaxa, 1988: 33-47.

Toluk A, Ayyıldız N 2011. Contributions to the Turkish Oribatid Fauna (Acari, Oribatida) from Bolu Province. Turkish Journal of Zoology, 35(1): 63-70.

Toluk A, Ayyildiz N, Baran S 2008. Two New Species of Epimerella Kulijev, 1967 (Acari, Oribatida, Epimerellidae) from Turkey. Journal of Natural History, 42(39-40): 2537-2546. 